\title{
Antimicrobial Effectiveness of Spices: an Approach for Use in Food Conservation Systems
}

\author{
Evandro Leite de Souza ${ }^{1 *}$, Tânia Lúcia Montenegro Stamford ${ }^{1}$, Edeltrudes de Oliveira \\ Lima $^{2}$, Vinícius Nogueira Trajano ${ }^{2}$ and José Maria Barbosa Filho ${ }^{3}$ \\ ${ }^{1}$ Programa de Pós-graduação em Nutrição; Departamento de Nutrição; Centro de Ciências da Saúde, Universidade \\ Federal de Pernambuco. ${ }^{2}$ Laboratório de Micologia; Departamento de Ciências Farmacêuticas; Centro de \\ Ciências da Saúde; Universidade Federal da Paraíba. ${ }^{3}$ Laboratório de Tecnologia Farmacêutica; Departamento de \\ Ciências Farmacêuticas; Centro de Ciências da Saúde; Universidade Federal da Paraíba; Rua Radialista Antônio \\ Assunção de Jesus, 680/102; Jardim Cidade Universitária; 58052-230; João Pessoa - PB - Brasil
}

\begin{abstract}
There has been constant an increasing the search alternative and efficient compounds for food conservation, aiming a partial or total replacement of antimicrobial chemical additives. Spices offer a promising alternative for food safety. Inhibitory activity of spices and derivatives on the growth of bacteria, yeasts, fungi and microbial toxins synthesis has been well reported, so they could be used in food conservation as main or as adjuvant antimicrobial compounds in order to assure the production of microbiologically stable foods.
\end{abstract}

Key words: Spices, essential oil, extracts, chemical compounds, antibacterial activity, antifungal activity

\section{INTRODUCTION}

Food conservation has been characterized for nutritious and microbiologically stable foods and it has been archived by controlling the growth of spoiling and pathogenic food-related microorganisms. Microbial control in foods could be assured by suppressing one or more essential factors for microbial survival (Horace, 1982). It could be possible by adding suitable substances (weak organic acids, hydrogen peroxide, chelators, organic biomolecules) and applying physical (temperature, packaging) and/or chemical procedures $(\mathrm{pH}$, oxide-reduction potential, osmotic pressure) (Ray, 1996; Brull and Coote, 1999). These procedures could kill or make unviable some microorganisms.

There has been increasing concern of the consumers about foods free or with lower level of chemical preservatives because these could be toxic for humans (Bedin et al., 1999). Concomitantly, consumers have also demanded for foods with long shelf-life and absence of risk of causing foodborne diseases. This perspective has put pressure on the food industry for progressive removal of chemical preservatives and adoption of natural alternatives to obtain its goals concerning microbial safety. This resulted in increasing search for new technologies for use in food conservation systems, wich include: modified atmosphere packaging, combined effect of underlethal procedures, alternative antimicrobial compounds (ecstatic or cidal effect), combination of conventional (used in low levels) and alternatives antimicrobials (Brull and Coote, 1999).

Uncontrolled use of chemical antimicrobial preservatives has been inducing factor for appearance of microbial strains more and more resistant to classic antimicrobial agents. Difficult 
to control the microbial survival, showed by isolation of multi-resistant strains, has been reported all over the world. Fifty years of increasing use of chemicals antimicrobials have created a situation leading to an ecological imbalance and enrichment of multiples multiresistant pathogenic microorganisms (Levy, 1997). The successful story of microbial chemocontrol lies in the continuous search for new antimicrobial substances to control the challenge posed by resistant strains (Notermans and HoogenboonVerdegaal, 1992). Antibiotic resistance in foodborne pathogens is a reality, though substantial qualitative and quantitative differences have been observed (Teuber, 1999). Strains of resistant foodborne pathogens to a variety of antimicrobials have become a major health concern (Kiessling et al., 2002) and it could decrease the successful application of control measures on spoilage and pathogen microorganisms, many times leading for use of less safe, ineffective or expensive alternatives (Levy, 1997).

Changes in/on the antimicrobial target, inactivation by enzymes, changes in cellular permeability, antimicrobial active efflux, overproduction of target enzymes and bypass of the antimicrobial have been common mechanisms of antimicrobial resistance (McKeegan et al., 2002). Brull and Coote (1999) have reported microbial resistance for some antimicrobials used in food conservation as weak-organic acids, hydrogen peroxide, chelators and some small organic biomolecules.

Recently, there has been increasing interest in discovering new natural antimicrobials (Sagdiç et al., 2003a), this is also has been true in food microbiology. Plant products with antimicrobial properties notably have obtained emphasis for a possible application in food production in order to prevent bacterial and fungal growth (Lanciotti et al., 2004). Plant products are characterized for a wide range of volatile compounds, some of which are important flavor quality factors (Utama et al., 2002). Moreover, plant volatiles have been generally recognized as safe (GRAS) (Newberne et al., 2000). Systematic screening for biological interactions between microorganisms and plant products has been valuable source of new and effective antimicrobial substances, which could have different action ways on/in the microbial cell when compared to other conventional antimicrobials. Plants synthesize by a secondary metabolism many compounds with complex molecular structures and some of them have been related with antimicrobial properties found in plant and their derivatives. Among these secondary metabolites are found alkaloids, flavonoids, isoflavonoids, tanins, cumarins, glycosides, terpens and phenolic compounds (Simões et al., 1999).

Being plant natural foodstuffs, spices appeal to consumers who tend to question the safety of synthetic additives (Farag et al., 1989; Sagdiç 2003b). Antimicrobial properties of spices have been documented in recent years and interest continues to the present (-El Shami et al., 1985; Akgul and Kivanç, 1988; Cosentino et al., 1999; Domans and Deans, 2000; Ristori et al., 2002; Radhakrishanan-Sridhar and Velusamy-Rajaopal, 2003). Still little information is available emphasizing the preservative and antimicrobial role of spices in the prevention of foods of the microbial action (Arora and Kaur, 1999).

Spices are recognized to stabilize the foods front the microbial deterioration. This could be observed when spices show initially high microbial charge and as time progresses, the microbial growth become progressively slower or it is eventually totally suppressed (Kizil and Sogut, 2003). Antimicrobial activity of spices depend on several factors, which includes: i) kind of spice, ii) composition and concentration of spice, iii) microbial specie and its occurrence level, iv) substrate composition and v) processing conditions and storage (Shelef, 1983; Farag et al., 1989)

Spices have been defined as plant substances from indigenous or exotic origin, aromatic or with strong taste, used to enhance the taste of foods (Germano and Germano, 1998). Spices include leaves (bay, mint, rosemary, coriander, laurel, oregano), flowers (clove), bulbs (garlic, onion), fruits (cumin, red chilli, black pepper), stems (coriander, cinnamon), rhizomes (ginger) and other plant parts (Shelef, 1983). Although, spices have been well known for their medicinal, preservative and antioxidant properties, they have been currently used with primary purpose of enhancing the flavor of foods rather than extending shelf-life (Aktug and Karapinar 1986, Ristori et al., 2002).

Spices active compounds have been included in class of naturally occurring food preservatives and have their inclusion in foods allowed by food production regulator offices (Brull and Coote, 1999). Several scientific reports describe the 
inhibitory effect of spices on a variety of microorganisms, although considerable variation for resistance of different microorganisms to a given spice and of the same microorganisms to different spices has been observed (Akgul and Kivanç, 1988).

Gould (1995) has emphasized the possible use of spices and derivatives like alternatives for inclusion in a new perspective of food conservation called "natural antimicrobial system", which could use the synergistic effect of antimicrobial compounds from animal, plant and/or microbial origin, more physical procedures in order to create an inhospitable environment for microbial survival in foods.

\section{ANTIBACTERIAL ACTIVITY}

Antibacterial activity of spices has been reported by several researchers. Aktug and Karapinar (1986) observed inhibitory action of thyme (Thymus vulgaris), mint (Mentha piperita) and laurel (Laurus nobilis) ground leaves and their extracts on $S$. aureus, $S$. typhimurium and $V$. parahaemolyticus. Thyme was most prominent antibacterial product being active up to concentration $0.5 \%(\mathrm{w} / \mathrm{v})$ for ground and $5000 \mathrm{ppm}$ (v/v) for extracts. Pandit and Shelef (1994) tested the antilisterial effect of 18 spices and observed significant inhibitory effect of rosemary (Rosmarinus officinalis) $(\geq 5 \% \mathrm{w} / \mathrm{v}$ ) and clove (Eugenia cariophylata) $(\geq 1 \% \mathrm{w} / \mathrm{v})$ on $L$. monocytogenes. Rosemary $(0.5 \% \mathrm{w} / \mathrm{w})$ and its essential oil $(1 \% \mathrm{v} / \mathrm{w})$ were when useful for pork sausage during storage at $5^{\circ} \mathrm{C}$ for 50 days. Grohs and Kunz (2000) observed that spices mixtures were able to inhibit the growth of various meatspoiling microorganisms (Bacillus subtillis, Enterococcus spp., Staphylococcus spp., E. coli K12 and Pseudomonas fluorescens) providing stabilizing effect on colour and smell of fresh portioned pork meat.

Study carried out by Al-Jedah et al. (2000) analyzed the action of combined spices, including cumin (Cuminum cyminum), coriander (Coriandrum sativum), mustard (Brassica juncea), black pepper (Pipper nigrum) and lemon (Citrus aurantifolia) on $V$. parahaemolyticus, $S$. aureus, $S$. tiphy and E. coli count in fish sauce, which showed that the spices mixtures were able to exert static effect on all assayed bacteria when in interaction with an initial inoculum of $1.0 \times 10^{4}$ CFU/mL, except on S. typhy.

Sagdiç et al. (2003b) assayed the inhibitory effect of methanolic extracts of seven Turkish spices on E. coli $0157: \mathrm{H} 7$ where myrtle $(2.0 \% \mathrm{v} / \mathrm{v})$, thyme $(0.5,1.0,1.5$ and $2.0 \% \mathrm{v} / \mathrm{v})$, cumin $(1.0,1.5$ and $2.0 \% \mathrm{v} / \mathrm{v})$ and oregano $(1.0,1.5$ and $2.0 \mathrm{v} / \mathrm{v})$ and showed prominent results as bactericidal in both paper disc and agitated liquid culture assay. However, it was also found that laurel $(0.5,1.0$, 1.5 and $2.0 \% \mathrm{v} / \mathrm{v})$ stimulated the growth of $E$. coli O157:H7. Leuchner and Zamparini (2002) studied the growth and survival of E.coli $\mathrm{O} 157$ and Salmonella enterica serovar enteridis in mayonnaise in presence of garlic (Allium cepa), ginger, mustard and ground clove. Garlic $(1 \% \mathrm{w} / \mathrm{v})$ and clove $(1 \% \mathrm{w} / \mathrm{v})$ which showed bacteriostatic and bactericidal effect, respectively, towards $S$. enterica and E. coli $\mathrm{O} 157$, and E. coli was more sensitive. These results are significant regarding the emergence of E. coli 0157 and S. enterica serovar enteridis as foodborne pathogens that have significant impact on the food industry. Moreover, these bacteria present various undesirable attributes of virulence that in combination make them some of the most serious threats for food safety (Proctor and Davis, 2000). Effect of clove extract on the production of vero-toxin by enterohemorrhagic E. coli (EHEC) 0157:H7 was investigated by Sakagami et al. (2000) where verotoxin production was inhibited by garlic extract $(0.5 \% \mathrm{w} / \mathrm{v})$.

Sakandamis et al. (2002) assayed the effect of oregano essential oil on the behavior of $S$. typhimurium in sterile and naturally contaminated beef fillets stored under aerobic and modified atmospheres (different levels of $\mathrm{CO}_{2}, \mathrm{O}_{2}, \mathrm{~N}_{2}$ and vacuum packing) and found that the addition of this essential oil $(0.8 \% \mathrm{v} / \mathrm{w})$ provided initial reduction of 1-2 log cycles CFU/g for $S$. typhimurium in all gaseous atmospheres. Outtara et al. (1997) analyzed the antibacterial activity of selected fatty acids and spices essential oils on meat spoilage bacteria and no fatty acid presented antibacterial activity. Brochothrix thermosphacta was inhibited by cinnamon, clove, garlic and rosemary essential oil $(1 / 100 \mathrm{v} / \mathrm{v}) ;$ Serratia liquefaciens by cinnamon, clove, garlic, pimento and rosemary essential oil $(1 / 100 \mathrm{v} / \mathrm{v})$; Carnobacterium piscicola by cinnamon, clove, pimento and rosemary essential oil $(1 / 100 \mathrm{v} / \mathrm{v})$; and Lactobacillus sake by cinnamon, clove, black pepper, pimento and rosemary essential oil (1/100 
v/v); L. curvatus was inhibited by black pepper and pimento essential oil $(1 / 100 \mathrm{v} / \mathrm{v})$.

Elgayyar et al. (2001) examined the effectiveness of cardamom, anise, basil, coriander, rosemary, parsley, dill and angelica essential oil for controlling the growth and survival of pathogenic and saprophytic microorganisms. The results showed inhibitory property for oregano, basil and coriander essential oil, which presented minimum lethal concentration $(\mathrm{v} / \mathrm{v})$ ranging between 8 and $50 \mathrm{ppm}$ for Pseudomonas aeruginosa, Stahylococcus aureus and Yersinia enterocolitica. Arora and Kaur (1999) analyzed the antimicrobial activity of garlic, ginger, clove, black pepper and ground green chilli and their aqueous extracts on human pathogenic bacteria including Bacillus sphaericus, Staphylococcus aureus, S. epidermidis, Enterobacter aerogenes, Escherichia coli, Pseudomonas aeruginosa, Salmonella tiphy and Shiguella flexneri and found that all tested bacteria were sensitive to ground garlic and its extract. Moreover, garlic extract showed considerable cidal effect on $S$. epidermidis, $S$. tiphy and E. aerogenes.

Kivanç et al. (1991) studied the effect of spices on starter cultures (Lactobacillus plantarum and Leuconostoc mesenteroides) considering that lactic acid bacteria are relatively resistant to toxic effect of spices and derivatives (Jansen et al., 1987) and that some spices have exerted stimulatory effect on these microorganisms resulting in enhanced acid production (Tiwari and Pandey, 1981). Cumin $(0.5,1.0$ and $1.0 \% \mathrm{w} / \mathrm{w})$ and its essential oil (150, 300 and 600ppm) stimulated the growth of $L$. plantarum and $L$. mesenteroides and acid production. Oregano was able to stimulate the growth of $L$. plantarum and acid production, however this behavior was not observed in $L$. mesenteroides.

Outtara et al. (1997) reported antimicrobial activity of many spices and classified their activities as strong, medium, or weak. Several studies (Shelef et al., 1980; Aureli et al., 1992; Conner, 1993) showed that cinnamon, clove, pimento, thyme, oregano and rosemary had strong and consistent inhibitory effect against several pathogen and spoiling bacteria.

Exact mechanism of antibacterial action of spices and derivatives is not yet clear (Lanciotti et al., 2004). Although some hypothesis habe been given, which involve: i) hydrophobic and hydrogen bonding of phenolic compounds to membrane proteins, followed by partition in the lipid bilayer (Juven et al., 1994); ii) perturbation of membrane permeability consequent to its expansion and increased fluidity causing the inhibition of membrane embedded enzymes (Cox et al., 2000); iii) membrane disruption (Caccioni et al., 2000); iv) destruction of electrons transport systems (Tassou et al., 2000); v) cell wall perturbation (Odhav et al., 2002). Generally, gram-negative bacteria have been reported to be more resistant than Gram-positive to essential oils antimicrobial effect because of their cell wall lipopolyssaccharide (Russel, 1991). Cell wall lipopolyssacaride may prevent that essential oils active compounds reach the cytoplasmic membrane of Gram-negative bacteria (Chanegriha et al., 1994).

\section{ANTIFUNGAL ACTIVITY}

Antifungal activity of spices and derivatives has been studied regarding viable cells count, mycelial growth and mycotoxins synthesis. Juglal et al. (2002) studied the effectiveness of nine essential oils to control the growth of mycotoxinsproducing moulds and noted that clove, cinnamon and oregano were able to prevent the growth of Aspergillus parasiticus and Fusarium moniliforme, while clove (ground and essential oil) markedly reduced the aflatoxin synthesis in infected grains. These findings could be useful for rural communities to prevent the synthesis of fungal toxins in contaminated grains by simple measures. Karapinar (1985) analyzed the inhibitory effect of various concentrations of mint, sage, bay, anise and ground red pepper $(0.5,1.0,2.0,4.0,8.0$, $16.0 \% \mathrm{w} / \mathrm{v})$ on the growth of Aspergillus parasiticus NRRL 2999 and its aflatoxin production and reported that only thyme presented significant delay on the fungal growth up to 10 days at 2.0\% and up to 30 days at 4.0, 8.0 and 16.0\%. Basílico and Basílico (1999) studied the inhibitory effect of oregano, mint, basil, sage and coriander on the mycelial growth of Aspergillus ochraceus NRRL 3174 and its ochratoxin synthesis and the results showed that oregano (750 $\mathrm{ppm})$ completely inhibited the fungal growth and ochratoxin A synthesis up to 14 days at $25^{\circ} \mathrm{C}$. Basil (750 ppm) was effective to inhibit the mycelial growth up to 7 days.

Thyagaraja and Hosono (1996) assayed the ability of chilli, coriander, pepper, cumin and asafoetida to inhibit food spoilage moulds (Rhizopus 
azygosporus, Mucor dimorphosphorous, Penicillium commune, Fusarium solani) and asafoetida showed promising results in inhibiting the fungal growth. Among the ethanolic and aqueous asafoetida extract, only ethanolic fraction showed antifungal property. Akgul and Kivanç (1988) studied antifungal activity of selected Turkish spices (black cumin, coriander, cumin, dill, laurel, oregano, parsley, spearmint, white mustard) on some foodborne fungi and found that oregano ground $(1.0,1.5,2.0 \% \mathrm{w} / \mathrm{v})$ and its essential oil $(0.05 \%, 0.025 \%)$ showed inhibitory effect on Aspergillus flavus, A. niger, Geotrichum candidum, Mucor spp., Penicillium roqueforti and oregano essential oil exhibited higher inhibitory effect than sorbic acid.

Abel-Hafez and El-Said (1997) analyzed the effect of garlic and onion extract on the mycoflora of pepper, cinnamon and rosemary and reported effectiveness of garlic extract up to $0.25 \%(\mathrm{v} / \mathrm{v})$ to inhibit the growth of Aspergillus flavus, A. fumigatus, A. niger, A. ochraceus, A. terreus, Penicillium chrysogenum, $P$. puberulum, $P$. citrinum, $P$. corylophilum, Rhizopus stolonifer, Stachybotrys chartarum, Eurotium chevalieri and Emericella nidulans. Onion extract at all assayed concentrations $(0.625,0.250$ and $0.125 \% \mathrm{v} / \mathrm{v}) \mathrm{did}$ not present significant inhibitory effect when compared to the control assay. Benkeblia (2004) observed inhibitory effect of onion (green and yellow) essential oil at concentrations 50, 100, 200, 300 and 500mL/L on Fusarium oxysporum, Aspergillus niger and Penicillium cyclopium. Elgayyar et al. (2001) analyzing the antimicrobial effect of selected plant essential oils found that anise essential oil was highly inhibitory on Aspergillus niger, Geotrichum and Rhodotorula, although it was not active on bacteria.

Arora and Kaur (1999) assayed the sensitivity of yeasts to spices aqueous extracts and found that garlic and clove extract were able to inhibit Candida acutus, C. albicans, C. apicola, C. catenulata. C. inconspicua, C. tropicalis, Rhodotorula rubra, Sacharomyces cerevisae and Trignopsis variabilis and in some cases strong cidal effect was observed. Grohs and Kunz (2000) observed that mixtures of ground spices (2 and 5\% $\mathrm{w} / \mathrm{v})$ were effective to inhibit the growth of Candida lipolytica. Adam et al. (1998) analyzed the antifungal activity of essential oils from oregano, sage, lavender and mint on human pathogen fungi and found prominent inhibition on Malassezia furfur, Trichophyton rubrum and
Trichosporum beigelii with minimum inhibitory concentration and lethal minimum inhibitory of, respectively, $0.25 \%$ and $1 \%$ (v/v). Minimum inhibitory concentration was understood as the lower essential oil concentration that caused total inhibition of fungal growth noted by formation of growth inhibition halos, while the minimum lethal inhibitory was understood as the lower essential oil concentration that killed the fungi inoculum detected by viable cells count.

Little information on spices and derivatives action on/in the fungal cell in order to promote fungistatic or fungicide effect. In general, inhibitory action of natural products on mould involves cytoplasm granulation, cytoplasmic membrane rupture and inactivation and/or inhibition of intercellular and extracellular enzymes. These biological events could take place separately or concomitantly culminating with mycelium germination inhibition (Cowan, 1999). Also, it is reported that plant lytic enzymes act in the fungal cell wall causing breakage of $\beta-1,3$ glycan, $\beta-1,6$ glycan and chitin polymers (Brull and Coote, 1999).

\section{CHEMICAL COMPOUNDS}

In addition to the studies on antimicrobial activity of spices and their extracts and essential oils, the antimicrobial effectiveness of their chemical compounds have also been investigated in order to improve the understanding about the cell targets of the molecules found in spices (Karatzas et al., 2000; Vasquez et al., 2001). Helander et al. (1998) assayed the effect of carvacrol, (+) carvone, thymol and trans-cynnamaldehyde on $E$. coli O157:H7 and S. thyphimurium and reported that carvacrol and thymol decreased the intracellular ATP content of $E$. coli cells while simultaneously the extracellular ATP increased. This indicated disruptive action of these compounds toward cytoplasmic membrane.

Delaquis and Mazza (1998) described antimicrobial properties of isothiocyanate derived from onion and garlic. For isothiocyanates, it was hypothesized that they inactivated extracellular enzymes through the oxidative cleavage of disulphide bonds (Brul and Coote, 1999). Delaquis and Mazza (1998) purposed that the formation of reactive thiocyanate radical could mediate the antimicrobial property. 
Ramos-Nino et al. (1996) found that benzoic acids, benzaldehydes and cinnamic acid were able to inhibit the growth of Listeria monocytogenes. The lipophylic molecular portion of these compounds were recognized as being responsible for this antimicrobial property .Ultee et al. (1999) reported that carvacrol induced depletion of intracellular ATP pool in Bacillus cereus as consequence of ATP reduced synthesis or hydrolysis, but there was no change in the ATP permeability for the plasmatic membrane. Cinnamaldehyde, a nonphenolic compound from many spices essential oils showed antimicrobial properties by inhibiting amino acid decarboxylase activity (Wendakoon and Sakaguchi, 1995). Allylhydroxycinnamates, which presented similarity to cinnamaldehyde, was reported to inhibit Pseudomonas fluorescens by cellular energy depletion (Baranowski and Nagel, 1982).

Hao et al. (1998a, 1998b) reported inhibitory effect of eugenol, active principle of clove essential oil, on L. monocytogenes in cooked beef and poultry at 5 and $15^{\circ} \mathrm{C}$. Karapinar and Aktug (1987) noted inhibitory effect of eugenol, thymol, menthol and anethole (volatile compounds found in several spices) at 50 and $500 \mu \mathrm{g} / \mathrm{mL}$ concentrations on Salmonella typhimurium, $S$. aureus and V. prahaemolyticus. Nakatani (2003) observed that monoterpens found in nutmeg and clove, lignans in papua mace and polymethoxylated phenols in alpinia presented promising antimicrobial activity. Campo et al. (2003) studied the most active phenolic compound from rosemary against $L$. monocytogenes regarding the influence of the phenolic compound concentration, $\mathrm{pH}$ and $\mathrm{NaCl}$ and noted that carnosic acid showed more effective than other assayed phenolic compounds (carnosol, 12methoxy carnosic, ferulic acid, caffeic acid, rosmarinic acid, luteolin and luteolin-7-glucoside). The mode by which microorganisms are inhibited by essential oils and their chemical compounds seems to involve different mechanisms. It has been hypothesized that the inhibition involves phenolic compounds, because these compounds sensitize the phospholipid bilayer of the microbial cytoplasmic membrane causing increased permeability, unavailability of vital intracellular constituents (Juven et al., 1994; Kim et al., 1995) and/or impairment of bacterial enzymes systems (Farag et al., 1989; Wendakoon and Skaguchi, 1995).
Reports have indicated that essential oils containing carvacrol, eugenol and thymol (phenolic compounds) had highest antibacterial performances (Lattaoui and Tantaoui-Elaraki, 1994; Kim et al., 1995). Many authors have emphasized that the antimicrobial effect of essential oil constituents has been dependent on their hydrophobicity and partition in the microbial plasmatic membrane. Effect of specific ions due to their addition in/on plasmatic membrane had great effect on the protons motive force, intracellular ATP content and overall activity of microbial cells, including turgor pressure control, solutes transport and metabolism regulation (Lanciotti et al., 2004).

\section{MICROBIOLOGICAL QUALITY OF SPICES}

Presence of pathogenic and spoiling microorganisms in spices could act as vehicles for microorganisms to enter in foods. Frequently, spices are grown and harvested in warm and humid areas where the growth of wide variety of microorganisms is readily supported (Mousuymi and Sarkat, 2003). As many other agricultural commodities, spices are exposed to a wide range of environmental microbial contamination during harvest, processing, and in retail markets by dust, waste water, and animal and even human excreta (Freire and Offord, 2003). The International Commission on Microbiological Specifications for Foods (1974) has set up maximum limit of $10^{6}, 10^{4}$ and $10^{3} \mathrm{CFU}$ of total aerobic mesophilic bacteria (TAMB), fungi, coliforms and E. coli, respectively, per gram spice (Zamboni et al., 1991). Brazilian Microbiological Standard for Foods (ANVISA, 2001) has set maximum limit of $5 \times 10^{2}$ e $10^{2} \mathrm{CFU} / \mathrm{g}$ for faecal coliforms and positive coagulase Staphhylococcus, respectively, and absence in $25 \mathrm{~g}$ of spices for Salmonella. In German legislation, standard limit value for TAMB, Bacillus cereus and S. aureus is $10^{5}, 10^{4}$ and $10^{2} \mathrm{CFU}$ per gram of spices, respectively (Mousuymi and Sarkat, 2003). The microbiological quality, the load of heterotrophus or Enterobacteriaceae in particular, often acts as indicator of the hygienic situation of the region where the spices are produced and processed (Schwab et al., 1982). 
Mousuymi and Sarkat (2003) reported the presence of various microorganisms including total heterotrophus, Bacillus cereus, Clostridium perfringens, Escherichia coli, Salmonella and toxigenic moulds in spices. Thus, there is strong need to evaluate and control the microbial quality of spices including bacterial and mycological analyses and presence of microbial toxic metabolites (Fernández et al., 1984; Zamboni et al., 1991; Oliveira et al., 1992; Toro Santa Maria et al., 1993; Hofman et al., 1994; Abdel-Hafez and Al-Said, 1997; Pereira et al., 1999; Freire and Offord, 2003; Benezet et al., 2003).

Antimicrobial activity of spices could be recognized as important factor for providing their inclusion in food conservation systems when pertinent measures are taken to assure their satisfactory microbiological quality. These measures must include action to control the moisture, good sanitary conditions in the processing, workers training, satisfactory transport conditions, proper storage, microbiological quality monitoring and actions of sanitary mark applied since harvest until insertion in foods.

\section{CONCLUSIONS}

Use of spices as microbial growth inhibitor in foods is often limited because of flavor considerations as effective antimicrobial dose may exceed the organoleptically accepted level (Pandit and Shelef 1994; Brull and Coote, 1999). Nonetheless, combinations of spices and other antimicrobial barriers could enhance the food shelf stability and microbial safety even in moderated levels. Due to this and due to the fact that spices are as GRAS, the antimicrobial properties of spices continue to be of interest (Pandit and Shelef, 1994). It is established that spices and their derivatives could be suitable alternatives for inclusion in food conservation systems and could act sometimes as main or adjuvant antimicrobial compounds. Before including spices and/or their derivatives in food conservation systems, some evaluations about microbiological quality, economic feasibility, antimicrobial effect for a long time and toxicity should be carried out.

\section{RESUMO}

Tem sido constante e crescente a busca por alternativos e eficientes compostos para conservação de total ou parcial substituição de aditivos antimicrobianos químicos tem sido crescente. As especiarias oferecem uma promissora alternativa para a segurança microbiana de alimentos. A atividade inibitória das especiarias e seus produtos derivados sobre o crescimento de bactérias, leveduras, fungos filamentosos e síntese de toxinas microbianas tem sido bem relatada, desta forma as especiarias poderiam ser utilizadas na conservação de alimentos como principais ou co-adjuvantes compostos antimicrobianos com vistas em assegurar a produção de alimentos microbiologicamente estáveis.

\section{REFERENCES}

Abdel-Hafez, S. I. I. and El-Said, A. H. M. (1997), Effect of garlic, onion and sodium benzoate on the mycoflora of pepper, cinnamon and rosemary in Egypt. International Biodeterioration \& Biodegradation, 39, 67-77.

Adam, K.; Sivropoulus, A.; Kokkini, S.; Lanaras, T. and Arsenakis, M. (1998), Antifungal activities of Origanum vulgare subsp. Hirtum, Mentha spicata, Lavandula angustifolia, and Salvia fruticosa essential oils against human pathogenic fungi. Journal of Agriculture and Food Chemistry, 46, 1739-1745.

ANVISA (2001), Regulamento técnico sobre padrões microbiológicos. Resolução - RDC n ${ }^{\circ} 12$. Brasil.

Akgul, A. and Kivanç, M. (1988) Inhibitory effect of selected Turkish spices and oregano components on some foodborne fungi. International Journal of Food Microbiology, 6, 263-268.

Aktug, S.E. and Karapinar, M. (1986), Sensitivity of some common food-poising bacteria to thyme, mint and bay leaves. International Journal of Food Microbiology, 3, 349-354.

Al-Jedah, J. H.; Ali, M. Z and Robinson, R. K. (2000), The inhibitory action of spices against pathogens that might be capable of growth in a fish sauce (mehiawah) from the Middle East. International Journal of Food Microbiology, 57, 129-133.

Arora, D. and Kaur, J. (1999), Antimicrobial activity of spices. International Journal of Antimicrobial Agents, 12, 257-262.

Aureli, P.; Constantini, A. and Zoles, S. (1992), Antibacterial activity of some plants essential oils against Listeria monocytogenes. Journal of Food Protection, 55, 344-348. 
Baranowski, J. D. and Nagel, C. W. (1982), Inhibition of Pseudomonas fluorescens by hidroxycinnamic acids and their alkyl esters. Journal of Food Science, 47, 1587-1589.

Basílico, M. Z. and Basílico, J. C. (1999), Inhibitory effects of some spices essential oils on Aspergillus ochraceus NRRL 3174 growth an ochratoxin A production. Letters in Applied Microbiology, 29, 238-241.

Bedin, C.; Gutkoski, S. B. and Wiest, J. M. (1999), Atividade antimicrobiana das especiarias. Higiene Alimentar, 13, 26-29.

Benezet, A.; Osa, J. M.; Pedregal, E.; Botas, M.; Olmo, N. and Perez-Flores, F. (2003), Microbiological quality of spices used in meat products. Alimentaria, 349, 65-71.

Benkeblia, N. (2004), Antimicrobial activity of essential oils extracts of various onions (Allium cepa) and garlic (Allium sativum). Lebensmittel Wissenchaft und-Technologie, 37, 263-268.

Brull, S. and Coote, P. (1999), Preservative agents in foods: mode of action and microbial resistance mechanisms. International Journal of Food Microbiology, 50, 1-17.

Caccioni, D. L. R.; Guizzardi, M.; Biondi, D. M.; Renda, A. and Ruberto, G. (2000), Relationships between volatile components of citrus fruit essential oil and antimicrobial action on Penicillium digitatum and Penicillium italicum. International Journal of Food Microbiology, 88, 170-175.

Campo, J.; Nguyen-The, C.; Sergent, M. and Amito, M. J. (2003), Determination of most bioactive phenolic compounds from rosemary against Listeria monocytogenes: influence of concentration, $\mathrm{pH}$ and $\mathrm{NaCl}$. Journal of Food Science, 68, 2066-2071.

Chanegriha, N.; Sabaou, N.; Baaliouamer, A. and Meklati, B. Y. (1994), Activité antibactérienne of antifongique de l'huile essentielle du cypress d'Algeric. Rivista Italiana Epposs, 12, 5-12.

Conner, D. E. (1993), Naturally occurring compounds. In: Davidison, P. M. and Branen, A. L (Eds). Antimicrobials in foods. New York : Marcel Dekker. pp. 441-468.

Cosentino, S.; Tuberoso, C. I. G.; Pisano, B.; Satta, M.; Mascia, V.; Arzedi, E. and Palmas, F. (1999), In-vitro antimicrobial activity and chemical composition of Sardinian Thymus essential oils. Letters in Applied Microbiology, 29, 130-135.

Cowan, M. M. (1999), Plant products as antimicrobial agents. Clinical Microbiology Review, 12, 564-582.

Cox, S. D.; Mann, C. M. and Markham, J. L. (2000), The mode of antimicrobial action of the essential oil of Malaleuca alternifolia (tea tree oil). Journal of Applied Microbiology, 88, 170-175.

Dellaquis, P. J. and Mazza, G. (1998), Antimicrobial properties of isothiocyanate in food preservation. Food Technology, 49, 73-84.
Domans, H. J. D. and Deans, S. G. (2000), Antimicrobial agents from plants: antibacterial activity of plant volatiles oils. Journal of Applied Microbiology, 88, 308-316.

Elgayyar, M.; Draughom, F. A.; Golden, D. A. and Mount, J. R. (2001), Antimicrobial activity off essential oils from plants against selected pathogenic and saprophytic microorganisms. Journal of Food Protection, 64, 1019-1024.

El-Shami, M. A.; Fadl, F. A.; Sirry, A. R. and El-Zayat, M. M. (1985), Antifungal property of garlic, clove juice compared with fungicidal treatment against Fusarium with watermelon. Egyptian Journal of Phytopathology, 17, 55-62.

Farag, R. S.; Daw, Z. Y.; Hewedi, F. M. and El-Baroty, G. S. A. (1989), Antibacterial activity of some Egyptian spices essential oils. Journal of Food Protection, 52, 665-667.

Fernandéz, J. E.; Kriviruchco, D. D. and Mitschele, O. J. (1984), Estúdio microbiológico de especiarias. Revista Argentina de Microbiologia, 16, 11-118.

Freire, F. C. O. and Offord, L. (2003), Bacterial and Yeasts counts in Brazilian commodities and spices. Brazilian Journal of Microbiology, 2, 145-148.

Germano, P. M. L. and Germano, M. I. S. (1998), Importância e riscos das especiarias. Higiene Alimentar, 12, 23-312.

Gould, G. W. (1995), Industry perspective on the use of natural antimicrobials and inhibitors for foods application. Journal of Food Protection, 45, 82-86.

Grohs, B. M. and Kunz, B. (2000), Use of spices for the stabilization of fresh portioned pork. Food Control, 11, 433-436.

Hao, Y. Y.; Bracket, R. E. and Doyle, M. P. (1998a), Inhibition of Listeria monocytogenes and Aeromonas hydrophila by plant extracts in refrigerated cooked beef. Journal of Food Protection. 61, 307-312.

Hao, Y. Y.; Bracket, R. E. and Doyle, M. P. (1998b), Efficacy of plant extracts in inhibiting Aeromonas hydrophila and Listeria monocytogenes in refrigerated poultry. Food Microbiology, 15, 367-378.

Helander, L. M.; Alakoni, H. L.; Latva-Kala, K.; Mattila-Sandholm, T.; Pol, L.; Smid, E. J.; Gorris, L. G. M. and Von Wright, A. (1998), Characterization of the action of selected essential oil components on gram-negative bacteria. Journal of Agriculture and Food Chemistry, 46, 3590-3595.

Hoffman, F.; Garcia-Cruz, C. H. and Vinturim, T. M. (1994), Qualidade higiênico-sanitária de condimentos e especiarias produzidas por uma indústria da cidade de São José do Rio Preto. Boletim Centro de Pesquisas e Processamento de Alimentos, 12, 81-88.

Horace, D.G. (1982), The safety of foods. Connecticut: Avi Publishing Company.

Jansen, A. M.; Scheffer, J. J. C. and Svendsen, B. (1987), Antimicrobial activities of essential oils. Literature review on possible application. Pharmacie, 9, 193-197. 
Juglal, S.; Govinden, R. and Odhav, B. (2002), Spices oils for the control of co-occuring mycotoxinproducing fungi. Journal of Food Protection, 65, 638-687.

Juven, B. J.; Kanner, J.; Sched, F. and Weisslowicz, H. (1994), Factors that interact with the antibacterial of thyme essential oil and its active constituents. Journal of Applied Microbiology, 76, 626-631.

Juven, B. J.; Kanner, J.; Sched, F. and Weisslowicz, H. (1989), Factors that interact with the antibacterial action of thyme essential oil and its active constituents. Journal of Applied Bacteriology, 76, 626-631.

Karapinar, M. (1985), The effects of citrus oil and some Turkish spices on growth and aflatoxin production by Aspergillus parasiticus NRRL 2999. International Journal of Food Microbiology, 12, 239-245.

Karapinar, M. and Aktug, S.E. (1987), Inhibition of food borne pathogens by thymol, eugenol, menthole and anethole. International Journal of Food Microbiology, 4, 161-166.

Karatzas, A. K., Bennit, M. H. J.; Smid, E. J. and Kets, E. P. W. (2000), Combined action of S-carvone and mild heat treatment on Listeria monocytogenes Scott A. Journal of Applied Bacteriology, 89, 296-301.

Kiessling, C. R.; Cutting, J. H.; Loftis, M., K; Kissling, V. W.; Data, A. R. and Sofos, J. N. (2002), Antimicrobial resistance of food retailed Salmonella isolates. Journal of Food Protection, 65, 603-608.

Kim, J.; Marshall, M. R. and Wei, C. (1995), Antibacterial activity pf some essential oils components against five foodborne pathogens. Journal of Agriculture and Food Chemistry, 43, 2839-2845.

Kivanç, M.; Akgul, A. and Dogan, A. (1991), Inhibitory and stimulatory effects of cumin, oregano and their essential oils on growth and acid production of Lactobacillus plantarum and Leuconostoc mesenteroides. International Journal of Food Microbiology, 13, 81-86.

Kizil, S. and Sogut, T. (2003), Investigation of antibacterial effects of spices. Crop Research, 3, 8690.

Lanciotti, R.; Gianotti, A.; Patrignani, N.; Belleti, N.; Guerzoni, M.E. and Gardini, F. (2004), Use of natural aroma compounds to improve shelf-life of minimally processed fruits. Trends in Food Science \& Technology, 15, 201-208.

Lattaouri, N. and Tantaoui-Elaraki, F. (1994), Individual and combined antibacterial activity of the main components of the three thyme essential oils. Rivista Italiana Epposs, 8, 13-19.

Leuchner, R. G. K. and Zamparini, J. (2002), Effects of spices on growth and survival of Escherichia coli 0157 and Salmonella enterica serovar enteridis in broth model systems and mayonnaise. Food Control, 13, 399-404.
Levy, S. W. (1997), Antibiotic resistance: an ecological imbalance. In: Chadwick, I. and Goode, J. (eds). Antibiotic resistance: origins, evolution, selection and spread. Chichester, Ciba Foundation Symposium, pp. 1-14.

McKeegan, K. S.; Borges-Walmsley, M. I. and Walmsley, A. R. (2002), Microbial and viral drug resistance mechanisms. Trends in Microbiology, 10, $8 \mathrm{~S}-14 \mathrm{~S}$.

Mousuymi, B. and Sarkat, P.K. (2003), Microbiological quality of some retail spices in India. Food Research International, 36, 469-474.

Nakatani, N. (2003), Biologically functional constituents of spices and herbs. Japanese Journal of the Society of Nutrition and Food Science, 56, 389395.

Newberne, P.; Smith, R.L.; Doull, J. and Feron, V.J. (2000), GRAS flavoring substances. Food Technology, 54, 66-83.

Notermans, S. and Hoogenboon-Verdegaal, A. (1992), Existing and emerging foodborne diseases. International Journal of Food Microbiology, 15, 197205.

Odhav, B.; Juglal, S. and Govinden, R. (2002), Spices Oliz for the control of co-occurring mycotoxinsproducing fungi. European Food Research and Technology, 65, 683-687.

Oliveira, L. A.; Franco, R. M. and Carvalho, J. C. A. P. (1992), Enterobacteriaceae em especiarias utilizadas na elaboração de embutidos cárneos. Higiene Alimentar, 6, 27-33.

Outara, B.; Simard, R .E.; Holley, R.A.; Piette, G.J.P. and Bégin, A. (1997) Antibacterial activity of selected fatty acids and essential oils against six meat spoilage organisms. International Journal of Food Microbiology, 37, 155-162.

Pandit, V. A. and Shelef, L. A. (1994), Sensitivity of Listeria monocytogenes to rosemary (Rosimarinus officinalis L.). Food Microbiology, 11, 57-63.

Pereira, M. S.; Oliveira, L. A. T.; Franco, R. M. and Carvalho, J. C. A. P. (1999), Contagem, isolamento e identificação de Bacillus cereus em condimentos preparados, utilizados em embutido cárneo (mortadela). Revista Brasileira de Ciência Veterinária, 6, 137-140.

Proctor, M. E. and Davis, J. P. (2000), Escherichia coli 0157:H7 infection in Wisconsin, 1992-1999. Wisconsin Medical Journal, 99, 32-37.

Radhakrishanan-Sridhar, S. and Velusamy-Rajaopal, R. (2003), Antifungal activity of some essential oils. Journal of Agriculture and Food Chemistry, 51, 7596-7599.

Ramos-Nino, M.E.; Clifford, M.N. and Adams, M.R. (1996), Quantitative structure activity relationship for the effect of benzoic acid, cinnamic acids and benzaldehydes on Listeria monocytogenes. Journal of Applied Microbiology, 80, 303-310. 
Ray, B. (1996), Fundamental Food Microbiology. New York : CRC Press.

Ristori, C. A.; Pereira, M. S. and Gelli, D. S. (2002), O efeito da pimenta do reino moída frente a contaminação in vitro com Salmonella rubislaw. Revista do Instituto Adolfo Lutz, 61, 131-133.

Russel, A. D. (1991), Mechanisms of bacterial resistance to non-antibiotics: food additives and pharmaceutical preservatives. Journal of Applied Bacteriology, 71, 191-201.

Sagdiç, O.; Karahan, A. G.; Ozcan, M. and Ozcan, G. (2003a), Effect of some spices extracts on bacterial inhibition. Food Science and Technology International, 9, 353-359.

Sagdiç, O.; Kusçu, A.; Ozcan, M. and Ozçelik, S. (2003b), Effect of Turkish spice extracts at various concentrations on the growth of E. coli $0157: \mathrm{H} 7$. Food Protection, 19, 473-480.

Sakagami, Y.; Kaioh, S.; Kajimura, K. and Yokoyamma, H. (2000), Inhibitory effect of clove extract on vero-toxin production by enterohemorrhagic Escherichia coli 0157:H7. Biocontrol Science, 5, 47-49.

Sakandamis, P.; Tsigarida, E. and Nichas, G. J. (2002), The effect of oregano essential oil on survival/death of Salmonella typhimurium in meat stored at $5^{\circ} \mathrm{C}$ under aerobic, VP/MAP conditions. Food Microbiology, 19, 97-103.

Schwab, A. H.; Harpestad, A. D.; Swartzentruber, A.; Lainer, J. M.; Wentz, B. A.; Duran, A. P.; Barnard, A. J. and Read Jr., R. B. (1982), Microbiological quality of some spices and herbs in retail markets. Applied and Environmental Microbiology, 44, 627630.

Shelef, L. A.; Naglik, O. A. and Bogen, D. W. (1980), Sensitivity of some common food-borne bacteria to the spices sage, rosemary and allspice. Journal of Food Science, 45, 1042-1044.

Shelef, L. A. (1983), Antimicrobial effects of spices. Journal of Food Safety, 6, 29-44.

Simões, C. M. O.; Schenckel, E. P.; Gosman, G.; Mello, J. C. P.; Mentz, L. A. and Perovick, P. R. (1999), Farmacognosia: da planta ao medicamento. Santa Catarina : UFSC e UFRGS.

Tassou, C. C.; Koutsoumanis, K. and Nychas, G. J. E. (2000), Inhibition of Salmonella enteridis and Staphyloccus aureus on nutrient both by mint essential oil. Food Research International, 48, 273280.

Teuber, M. (1999), Spread of antibiotic resistance with food-borne pathogens. Cellular and Molecular Life Science, 56, 755-763.

Thyagaraja, N. and Hosono, A. (1996), Effect of spice extract on fungal inhibition. LebensmittelWissenchaft und-Technologie, 29, 286-288.

Tiwari, K. P. and Pandey, A. (1981), Effect of some essential oils on lactic acid bacteria. Journal of Food Science Research, 3, 161-16381.
Toro Santa Maria, M. A.; Díaz, S. R. and Piazze, M. P. F. (1993), Microhongos filamentosos y levaduriformes associados a pimienta negra (Pipper nigrum). Boletín de Micologia, 8, 77-83.

Ultee, A.; Kets, E. P. W. and Smid, E. J. (1999), Mechanism of action of carvacrol on foodborne pathogens Bacillus cereus. Applied and Environmental Microbiology, 65, 4606-4610.

Utama, J. M. S.; Wills, R. B. H.; Ben-Yehoshua, S. and Kuesk, C. (2002), In vitro efficacy of plant volatiles for inhibiting the growth of fruit and vegetal decay microorganisms. Journal of Agriculture and Food Chemistry, 50, 6371-6377.

Vasquez, B. I.; Fente, C.; Franco, C. M.; Vasquez, M. J. and Cepeda, A. (2001), Inhibitory effects of eugenol and thymol on Penicillium citrium strains in culture media and cheese. International Journal of Food Microbiology, 67, 157-163.

Wendakoon, C. N. and Sakaguchi, M. (1995), Inhibition of amino acid decarboxylase activity of Enterobacter aerogenes by active components of spices. Journal of Food Protection, 58, 280-283.

Zamboni, C. D.; Alves, H. I.; Rodrigues, R. M. M. S.; Spiteri, N.; Atui, M. C. and Santos, M. C. (1991), Fraudes e Sujidades em condimentos comercializados na cidade de São Paulo. Revista do Instituto Adolfo Lutz, 51, 19-22.
Received: August 06, 2004; Revised: November 12, 2004; Accepted: May 23, 2005. 